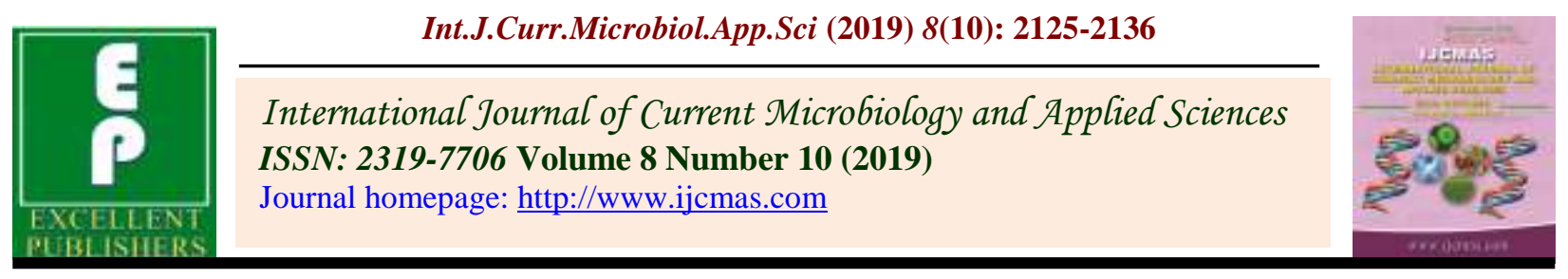

Review Article

https://doi.org/10.20546/ijcmas.2019.810.247

\title{
Bringing Unconventional Greens from Fodder to Fork: A Review
}

\author{
Nidhi Joshi* and Kiran Bains \\ Department of Food and Nutrition, Punjab Agricultural University, \\ Ludhiana, Punjab-141004, India \\ *Corresponding author
}

\begin{tabular}{|l|}
\hline Ke y w o r d s \\
Unconventional \\
greens, \\
Antioxidants, \\
Value-added \\
products, Turnip \\
leaves
\end{tabular}

Unconventional greens are underutilized greens that are not part of a normal diet or grown commercially on a large scale. Unconventional greens possess immense nutritional potential which can contribute towards nutritional security. Unconventional greens are micronutrient dense nature's gift to mankind that provides vitamins and minerals along with antioxidants. They are inexpensive sources of micronutrients such as ascorbic acid, vitamin $A, \beta$ carotene, folic acid, riboflavin, tocopherols, calcium, iron, phosphorus, magnesium, phytochemicals, antioxidants, and essential fatty acids. Increasing the consumption of unconventional greens in our diet can be a food-based approach for treating micronutrient deficiency. These unconventional greens are easily available in the vegetable market at no cost. These are not utilized by general masses rather used for cattle feed due to lack of awareness about their nutritional value. Intake of unconventional greens in the daily diet can be one of the strategies for improving nutritional status. The unconventional vegetable greens are gaining importance as a means to increase the per capita availability of food, hence, it can be explored to improve the nutritional scenario of the country.

\section{Introduction}

About 600 species constitute the global diversity in vegetable crops but only one fourth is utilized as a major vegetable crop and rest are named as underutilized, underexploited, unconventional, minor, rare vegetables or so on (Pandey et al., 2014). In nature, there are many underexploited greens with promising nutritive value, which can nourish the ever-increasing human population. Many of them are tolerant to adverse climatic conditions. India is blessed with diverse agroclimatic conditions with a vast resource of vegetable greens, many of which are still under-exploited (Kowsalya and Mohandas, 1999). Many traditional and underutilized vegetable crops are an essential source of vitamins and micronutrients and thus a valuable component to attain nutritional 
security. Their consumption provides diversity in daily food intake and adds taste and flavor to the diet. Unconventional greens are inexpensive but high-quality nutritional sources for the poor segment of the population, especially where malnutrition is widespread (Nnamani et al., 2009).

Unconventional greens being a rich source of phytochemicals and phenolic compounds contribute enormously to the antioxidant activity in the diet (Uusiku et al., 2010). The nutritive potential of some less commonly used and inexpensive vegetable greens has not yet been adequately studied. Consumption of such vegetable greens is confined to the people living in areas where they grow.

Nutritive value of commonly consumed leafy vegetables has been studied extensively, but there is very little information available on the nutritive value of unconventional leafy vegetables (Pattan and Devi, 2014).

In India, where both malnutrition and poverty are widespread in spite of the availability of various types of nutritious and cheap green leafy vegetables, there is a need for the exploration of unconventional and underutilized vegetable greens to overcome nutritional problems.

Many varieties of vegetable greens, for instance, the leaves of carrot, cauliflower, chickpea, colocasia, radish, and turnip are rich in micronutrients and antioxidants but are usually discarded or not used for human consumption (Joshi and Mathur, 2010). The aim of this paper is to review the current knowledge on the nutritional composition of unconventional greens mainly turnip, radish, carrot and cauliflower leaves and various value-added products developed at the household level.

Nutritional composition of unconventional greens
The unconventional vegetable greens possess a tremendous potential to help people overcome the deadly diseases of modern society. Underutilized green leafy vegetables are good sources of many nutrients like ascorbic acid, $\beta$-carotene, calcium and iron along with high fiber content. Cultivation of these greens could help in overcoming micronutrient malnutrition at negligible cost (Gupta et al., 2005). Proximate composition of thirty-eight underutilized green leafy vegetables was analyzed by Sheela et al., (2004). The results showed that the iron content of the leaves ranged between 3.68 to $37.34 \mathrm{mg} / 100 \mathrm{~g}$, the highest iron content was observed in Portulaca oleracea (37.34 mg). Calcium content ranged from 73 to 400 $\mathrm{mg} / 100 \mathrm{~g}$, with the maximum content in Oxalis acetosella $(400 \mathrm{mg})$. The highest ascorbic acid content was found in knol-khol greens.

Antinutritional factors; oxalate and phytate content in green leafy vegetables ranged between 101.82 to $825 \mathrm{mg} / 100 \mathrm{~g}$ and 202.02 to $720.69 \mathrm{mg} / 100 \mathrm{~g}$, respectively. Moyoet al., (2013) conducted the phytochemical analysis of three unconventional leafy vegetables namely, Amaranthus duius, Cleome gynandra, and Cucurbita maxima. The results of the study showed that unconventional greens had higher levels of phytochemicals and also exhibited more potent antioxidant activity as compared to commercial varieties. Pattan and Devi (2014) analyzedthe nutritional composition and anti-nutritional factors of selected fifteen dehydrated unconventional leafy vegetables. The results showed that iron, calcium, tannins and oxalate content ranged between 18.3 to $104 \mathrm{mg} / 100 \mathrm{~g}, 104$ to 388 $\mathrm{mg} / 100 \mathrm{~g}, 161$ to $1688 \mathrm{mg} / 100 \mathrm{~g}$ and 45 to $275 \mathrm{mg} / 100 \mathrm{~g}$ respectively. Sadana and Hira (2004) evaluated the nutrient composition of saags prepared from unconventional greens namely kail, Palampur dark green, Palampur 
light green, and Chinese sarson no.1. Nutritional evaluation of prepared recipes revealed that these greens were rich sources of iron, calcium, beta carotene, and ascorbic acid.

Turnip greens are leafy tops of the plant turnip (Brassica rapa) belonging to the Brassicaceae family. Greens are the finest source of vitamins, minerals, and health-benefiting antioxidants. These are light green, broad leaves with long petiole rising directly from its root top, having a taste similar to mustard greens but with a less intense spicy flavor. Turnip greens are available from November until February. Turnip edible parts contain a variety of organic compounds with biological activity such as glucosinolates, phenolics, flavonoids, phenylpropanoids and organic acids (Fernandes et al., 2007). According to Food Composition Tables (Gopalan et al.,2009), $100 \mathrm{~g}$ of fresh turnip leaves contain $4 \mathrm{~g}$ protein, $1.5 \mathrm{~g}$ fat, $9.4 \mathrm{~g}$ carbohydrates, $1 \mathrm{~g}$ crude fibre, $2.2 \mathrm{~g}$ minerals, $9396 \mu \mathrm{g}$ carotene, $180 \mathrm{mg}$ vitamin C, $710 \mathrm{mg}$ calcium, $28.4 \mathrm{mg}$ iron, $60 \mathrm{mg}$ phosphorus and $67 \mathrm{Kcal}$ energy. Beltagy (2014) investigated antimicrobial and antioxidant activities of Brassica rapa $\mathrm{L}$. The antioxidant activity of four extracts of root and aerial parts of turnip together with six ethanolic subfractions of both organs were examined for radical scavenging activity of DPPH. The percent scavenging ability on DPPH and EC50 value of root extract ranged between 11.11 to $86.30 \%$ and 4.45 to 203.87 $\mathrm{mg} / \mathrm{ml}$, respectively. The percent scavenging ability on DPPH and EC50 value of leaf extract ranged between 13.70 to $83.72 \%$ and 8.07 to $161.09 \mathrm{mg} / \mathrm{ml}$, respectively. All the tested fractions and crude extracts had positive inhibitory effects against Bacillus subtilis, Candida albicans, and Pseudomonas aeruginosa. The aqueous extracts of both roots and leaves were found to possess the strongest DPPH radical scavenging antioxidant activity. Fernandes et al., (2007) investigated the chemical and antioxidative capacity of dietary turnip (Brassica rapa var. rapaL.). The organic acids and phenolic compounds of distinct turnip edible parts (leaves and stems, flower buds and roots) were determined. The results revealed a profile composed of 14 phenolic and six organic acids. The quantification of the identified compounds showed that kaempferol 3-Osophoroside-7-O-glucoside, kaempferol 3-O(feruloyl/caffeoyl)-sophoroside-7-O-

glucoside, isorhamnetin 3,7-O-diglucoside and isorhamnetin 3-O-glucoside were the major phenolics and malic acid was the organic acid present in highest amounts. The study concluded that the turnip flower buds exhibited the strongest antioxidant capacity followed by leaves and roots. In another study, flavonoids and hydroxycinnamic derivatives in turnip tops were investigated (Romani et al., 2006). Turnip tops exhibited high polyphenols content ranging from 107 to 191 $\mathrm{mg} / 100 \mathrm{~g}$ on a fresh weight basis while the total flavonoids and hydroxycinnamic derivatives ranged between 101.56 to 138.85 $\mathrm{mg} / 100 \mathrm{~g}$ and 5.77 to $52.4 \mathrm{mg} / 100 \mathrm{~g}$, respectively. The total phenolics as determined by folin-ciocalteau method ranged from 221.46 to $250.69 \mathrm{mg} \mathrm{GAE} / 100 \mathrm{~g}$. The results obtained from the study showed that turnip tops are an appreciable source of polyphenols, especially flavonoids.

Saeed et al., (2012) investigated the nutritional attributes and the antioxidant activity of turnip by two different methods, DPPH assay and reducing power activity assay. The results of the study revealed that the methanolic extract of yellow turnip showed the highest radical scavenging activity (23.2 to $72.1 \%$ ) than white turnip (18.3 to $65.2 \%$ ) at $0.5-2.5 \mathrm{mg} / \mathrm{ml}$ and same trends were found in reducing power activity assay. The data obtained in the in vitro models clearly establish a strong antioxidant potency of Brassica rapa (turnip) extracts. The phytochemical composition of fresh turnip leaves and the effect of the blanching 
process were studied by Abdel-Fattah (2014). The fresh turnip leaves contain $0.61 \mathrm{mg} / 100 \mathrm{~g}$ of chlorophyll A; $0.22 \mathrm{mg} / 100 \mathrm{~g}$ of chlorophyll $\mathrm{B} ; 0.83 \mathrm{mg} / 100 \mathrm{~g}$ of total chlorophyll; $0.33 \mathrm{mg} / 100 \mathrm{~g}$ of total carotenoids; $1196.80 \mathrm{mg}$ GAE/100 $\mathrm{g}$ of total phenols and $808.55 \mathrm{mg} \mathrm{QE} / 100 \mathrm{~g}$ of total flavonoids. On the other hand, the blanched turnip leaves contain $0.52 \mathrm{mg} / 100 \mathrm{~g}$ of chlorophyll A, $0.12 \mathrm{mg} / 100 \mathrm{~g}$ of chlorophyll $\mathrm{B}, 0.64 \mathrm{mg} / 100 \mathrm{~g}$ of total chlorophyll, 0.26 $\mathrm{mg} / 100 \mathrm{~g}$ of total carotenoids, $1084.85 \mathrm{mg}$ GAE/100 $\mathrm{g}$ of total phenols and $289.73 \mathrm{mg}$ $\mathrm{QE} / 100 \mathrm{~g}$ of total flavonoids. The results of the study revealed that the blanching process decreased the bioactive components in leaves. Siddiqui et al., (2006) studied photosynthesis and chlorophyll content in the turnip leaves. The findings of the study revealed that turnip leaves contain $11.23 \mathrm{mg} / \mathrm{ml}$ of chlorophyll A, $8.73 \mathrm{mg} / \mathrm{ml}$ of chlorophyll $\mathrm{B}$ and $19.78 \mathrm{mg} / \mathrm{ml}$ of total chlorophyll. The ratio of $\mathrm{Chl} \mathrm{a/} \mathrm{Chl} \mathrm{b}$ was found to be $1.29 \pm 0.03$.

Raphanus sativus L. commonly known as radish is a member of the Brassicaceae family. It is an essential vegetable crop in India. Its roots, leaves, and fruits are edible. All parts of the plant have immense ethnomedicinal uses. $100 \mathrm{~g}$ of fresh radish leaves contain $2.22 \mathrm{~g}$ protein, $0.51 \mathrm{~g}$ fat, 2.77 $\mathrm{g}$ carbohydrates, $1.82 \mathrm{~g}$ crude fibre, $1.6 \mathrm{~g}$ minerals, $9339 \mu \mathrm{g}$ total carotenoids, $2591 \mu \mathrm{g}$ beta carotene, $65.76 \mathrm{mg}$ vitamin C, $234 \mathrm{mg}$ calcium, $3.82 \mathrm{mg}$ iron, $27.57 \mathrm{mg}$ total polyphenols and $109 \mathrm{KJ}$ energy (Longvah et al., 2017). Beeviet al., (2010) investigated polyphenolic content, antioxidant and radical scavenging activity of aerial parts of radish. Methanolic and acetone extracts of radish leaves were found to have total polyphenolic content of 86.16 and $78.77 \mathrm{mg} / \mathrm{g}$ of dry extract, respectively. It was also found to scavenge free radicals effectively with $\mathrm{IC}_{50}$ value of 31 and $42 \mathrm{mg} / \mathrm{ml}$. Thus, radish leaves were regarded as a potential source of natural antioxidants. In a study by Reddy et al.,
(2010), ethanolic extracts of radish leaves exhibited 45-50\% DPPH radical inhibition at $200 \mu \mathrm{g} / \mathrm{ml}$ concentration. Agarwal and Varma (2014) studied radical scavenging ability and biochemical screening of different extracts of Raphanus sativus L. The results of the study revealed that $\mathrm{IC}_{50}$ value of ethanolic leaf extract was found to be $122.33 \mu \mathrm{g} / \mathrm{ml}$ with maximum percent inhibition of $78.17 \%$ at 200 $\mu \mathrm{g} / \mathrm{ml}$ concentration while minimum percent inhibition of $23.86 \%$ was found at $50 \mu \mathrm{g} / \mathrm{ml}$ concentration. The results of the quantitative phytochemical analysis of leaves showed the presence of $3.40 \mathrm{mg} / \mathrm{g}$ fresh weight of photosynthetic pigments and $0.0375 \mathrm{mg} / \mathrm{g}$ fresh weight of foliar phenol content. Qualitative phytochemical analysis of leaves showed the presence of alkaloids, flavonoids, glycosides, tannin and phenolic compounds as well as triterpenoids and steroids. Leaf extract was found to be a more potent antioxidant as compared to the root.

Devaraj et al., (2011) studied the protective effect of leaves of Raphanus sativus L. on experimentally induced gastric ulcers in rats. Preliminary phytochemical screening of the leaf extracts revealed the presence of steroids in petroleum ether extract and saponins and alkaloids in chloroform extract. The ethyl extract showed the presence of proteins, saponins, glycosides, and flavonoids while aqueous extract had carbohydrates, proteins, alkaloids, saponins, flavonoids, and glycosides. The tannins were found to be present in ethanolic extract along with all the constituents present in the aqueous extract. The major carotenoids in Indian leafy vegetables using high-performance liquid chromatography were determined by Lakshminarayana et al., (2005). The results of the study revealed that radish leaves contain $3.3 \mathrm{mg} / 100 \mathrm{~g}$ neoxanthin, $22.3 \mathrm{mg} / 100 \mathrm{~g}$ lutein, $11.2 \mathrm{mg} / 100 \mathrm{~g} \beta$-carotene and 42.95 $\mathrm{mg} / 100 \mathrm{~g}$ total carotenoids. In another study by Ankita and Prasad (2015), the concentration of chlorophyll and carotene in 
fresh radish leaves was found to be 105.76 $\mathrm{mg} / 100 \mathrm{~g}$ and $3.96 \mathrm{mg} / 100 \mathrm{~g}$, respectively.

Cauliflower green leaves are rich sources of micronutrients and belong to the family of Brassicaceae. $100 \mathrm{~g}$ of fresh cauliflower leaves contain $3.9 \mathrm{~g}$ protein, $0.42 \mathrm{~g}$ fat, $3.39 \mathrm{~g}$ carbohydrates, $3.43 \mathrm{~g}$ crude fibre, $1.22 \mathrm{~g}$ minerals, $96.70 \mathrm{mg}$ calcium, $2.42 \mathrm{mg}$ iron, $52.84 \mathrm{mg}$ vitamin $\mathrm{C}, 146 \mu \mathrm{g} \beta$-carotene, 1742 $\mu \mathrm{g}$ total carotenoids, $28.94 \mathrm{mg}$ total polyphenols and $148 \mathrm{KJ}$ energy (Longvah et al., 2017). Chakarborty and Datta (2016) estimated macro-nutrients in domestically processed cauliflower leaf powder (CLP). The results revealed that $100 \mathrm{~g}$ of CLP contained $319.88 \mathrm{Kcal}$ energy; $40.14 \mathrm{~g}$ carbohydrates; $27.77 \mathrm{~g}$ protein; $5.36 \mathrm{~g}$ fat; $8.55 \mathrm{~g}$ fiber; 13.98 $\mathrm{g}$ total ash and $4.2 \%$ moisture. Therefore, cauliflower leaves which are generally thrown away can be utilized to improve the nutritional status of the population. Singh et al., (2001) estimated the nutritional composition of cauliflower leaves. The findings of the study revealed that cauliflower leaves contained $29.9 \mathrm{mg} / 100 \mathrm{~g}$ of protein, $42.4 \mathrm{mg} / 100 \mathrm{~g}$ of ascorbic acid, $7.2 \mathrm{mg} / 100 \mathrm{~g}$ of beta carotene and $66.8 \mathrm{mg} / 100 \mathrm{~g}$ of total iron. The efficacy of preparations of cauliflower greens in improving blood hemoglobin in selected adolescent girls was demonstrated by Mohankumar and Bhawani (2004). The results of the study revealed that $100 \mathrm{~g}$ of cauliflower leaves contain $25.1 \mathrm{mg}$ iron, $260 \mathrm{mg}$ calcium and $29 \mathrm{mg}$ vitamin C. The porial developed by the incorporation of cauliflower leaves provided $16.4,262.9$ and $13.85 \mathrm{mg} / 100 \mathrm{~g}$ of iron, calcium and vitamin $\mathrm{C}$, respectively. The study concluded that the blood hemoglobin level can be successfully elevated in adolescent girls by incorporating cauliflower leaves in their daily diet

As per Indian Food composition tables, $100 \mathrm{~g}$ of fresh carrot leaves contain $5.1 \mathrm{~g}$ protein, 0.5 $\mathrm{g}$ fat, $13.1 \mathrm{~g}$ carbohydrates, $1.9 \mathrm{~g}$ crude fibre, $2.8 \mathrm{~g}$ minerals, $5700 \mu \mathrm{g}$ carotene, $124 \mathrm{mg}$ vitamin C, $340 \mathrm{mg}$ calcium, $110 \mathrm{mg}$ phosphorus, $8.8 \mathrm{gm}$ iron and $77 \mathrm{Kcal}$ energy (Gopalan et al., 2009). Leite et al., (2011) studied the chemical characterization of leaves of organically grown carrots in various stages of development for use as food. The leaves were dehydrated in an oven at $70^{\circ} \mathrm{C}$ and analyzed for chemical composition, antioxidant activity, chlorophyll content, fatty acid composition, and minerals. The analysis revealed that 100 days of development as the ideal stage for removal and consumption of carrot leaves with good antioxidant activity requiring only $63.78 \mathrm{mg} / \mathrm{L}$ of methanolic extract to inhibit $50 \%$ of the concentration of free radical DPPH. The alpha-linolenic acid and protein content were found to be 876.55 $\mathrm{mg} / 100 \mathrm{~g}$ and $18.23 \% \mathrm{mg} / 100 \mathrm{~g}$, respectively. Meena et al., (2015) studied the effect of blanching and drying on antioxidant activity of selected green leafy vegetables. The findings of the study revealed that fresh carrot greens have $11.64 \mathrm{mg} / 100 \mathrm{~g}$ GAE of total phenols, $10.45 \mathrm{mg} / 100 \mathrm{~g}$ QE of flavonoids and $43.5 \mathrm{mg} / 100 \mathrm{~g}$ AAE of antioxidant activity. Drying caused a substantial increase in the concentration of nutrients, phenols, flavonoids and antioxidant activity. The concentration of total phenols, flavonoids and antioxidant activity in dried carrot leaves were 95.34 $\mathrm{mg} / 100 \mathrm{~g} \mathrm{GAE}, 78.7 \mathrm{mg} / 100 \mathrm{~g} \mathrm{QE}$ and 421.6 mg/100 g AAE, respectively. De AlmeidaMuradianet al., (1998) investigated vitamin A concentration in carrot leaves using highperformance liquid chromatography and open column chromatography. The findings of the study revealed that the concentration of vitamin A in carrot leaves using open column chromatography was $491 \mathrm{RE} / 100 \mathrm{~g}$ while it was found to be $495 \mathrm{RE} / 100 \mathrm{~g}$ when analyzed on HPLC.

In a study by Martin et al., (2012), the methanolic extract of radish and carrot leaves was found to have total phenolic content of $35.3 \mathrm{GAE} / \mathrm{kg}$ and $13.5 \mathrm{GAE} / \mathrm{kg}$, respectively. Whereas the ethanolic extract of radish and 
carrot leaves have total phenolic content of 36.7 GAE $/ \mathrm{kg}$ and 12.4 GAE/kg, respectively. Eugenio et al., (2016) evaluated antioxidant activity and phenolic compounds in carrot and radish leaves. The findings of the study revealed that iron-reducing antioxidant power (FRAP), total phenolics and $\mathrm{DPPH} / \mathrm{IC}_{50}$ value of radish leaves were $6658.5 \mathrm{M}$ ferrous sulfate $/ \mathrm{g}, 91.8 \mathrm{mg}$ GAE/g and $422.7 \mathrm{~g} / \mathrm{g}$, respectively. Similarly, iron-reducing antioxidant power (FRAP), total phenolics and $\mathrm{DPPH} / \mathrm{IC}_{50}$ value of carrot leaves were 690.3 $\mathrm{M}$ ferrous sulfate/g, $41.2 \mathrm{mg} \mathrm{GAE} / \mathrm{g}$ and $1577.7 \mathrm{~g} / \mathrm{g}$, respectively. HPLC/DAD analysis showed the presence of a high concentration of chlorogenic acid $(458.79 \mathrm{mg} / \mathrm{L})$ in carrot leaves.

Shehata et al., (2014) determined total polyphenols, flavonoids and antioxidant activity of radish, carrot and cauliflower leaves. Leaves were extracted with cold and boiled water. The results of the study revealed that cold water extract of carrot, radish, and cauliflower leaves have total polyphenols, flavonoids and DPPH free radical scavenging activity in the range of 10.73 to $61.75 \mathrm{mg}$ GAE/100 g, 138 to $299 \mathrm{mg}$ RUE/100 $\mathrm{g}$ and 19.2 to $31.5 \%$, respectively. The concentration of total polyphenols, total flavonoids and DPPH free radical scavenging activity in boiled water extract were in the range of 16.25 to $57.53 \mathrm{mg}$ GAE/100 g, 92 to $368 \mathrm{mg}$ RUE/100 g and 15.2 to $70.65 \%$, respectively.

\section{Value-added products from unconventional greens}

Unconventional vegetable greens are a reservoir of essential vitamins, micronutrients, protein, and other phytonutrients that have the potential to play a major role in strategies to attain food and nutritional security. Various value-added products have been developed by incorporating unconventional greens in various forms. The developed products provide an alternative way to increase the consumption of unconventional greens with good consumer appeal and varied use.

Kulkarni (2003) developed a number of valueadded food products using underutilized leafy vegetables. The nutrients such as protein, iron, $\beta$-carotene, and ascorbic acid ranged from $2.43 \mathrm{~g}$ (groundnut chutney with chakramuni leaves) to $15.71 \mathrm{~g}$ (barnyard millet upma with drumstick leaves), 1.40mg (groundnut chutney with chakramuni leaves) to $12.94 \mathrm{mg}$ (little millet dosa with chakramuni leaves), $15.63 \mu \mathrm{g}$ (groundnut chutney with chakramuni leaves) to 2338.09 $\mu \mathrm{g}$ (drumstick chapathi with soybean) and $0.40 \mathrm{mg}$ (coconut chutney) to $946.80 \mathrm{mg}$ (both variations of turdal bhaji with chakramuni and chandanabatta leaves) per serving, respectively. In another study, Singh and Awasthi (2003) studied the nutrient composition of products namely murukku, biscuits, mathriand namakpare incorporated by colocasia, drumstick and curry leaves. The protein, iron and $\beta$-carotene content of the products ranged from 11.6 to $23.8 \mathrm{~g} / 100 \mathrm{~g}$, 2.16 to $5.62 \mathrm{mg} / 100 \mathrm{~g}$ and 819.2 to 3017.75 $\mu \mathrm{g} / 100 \mathrm{~g}$, respectively. Shah (2005) carried out a study on the proximate composition of recipes with chickpea leaves. The study revealed that protein and iron content in shev, chakli, mung dal, and udad dal wadawere $16.66 \mathrm{~g}$ and $7.8 \mathrm{mg}, 11.66 \mathrm{~g}$ and $21.58 \mathrm{mg}$, $21.58 \mathrm{~g}$ and $9.50 \mathrm{mg}, 16.91 \mathrm{~g}$ and $9.10 \mathrm{mg}$, respectively.

Chauhan and Inteli (2015) investigated the acceptability of food products incorporated with dried cauliflower green leaves. Three recipes (pancakes, dhokla, and idli) were supplemented with 2 and $5 \mathrm{~g}$ cauliflower leaf powder per serving. Biochemical estimation found that $100 \mathrm{~g}$ of cauliflower leaf powder contains $34 \%$ moisture, 10.23 g crude fiber, 62 $\mathrm{mg}$ iron, and $21.6 \mathrm{~g}$ protein. The prepared recipes were found to be acceptable at $2 \mathrm{~g}$ 
incorporation of leaf powder. It was concluded that cauliflower leaf powder due to its high iron content can be used as a supplement to make low-cost iron-rich recipes. Banka et al., (2017) developed iron-rich value-added products by incorporating leaves of cauliflower, carrot, beet, and turnip. Four commonly consumed products namely chakali, namakpara, bhujia, and tarts were developed by incorporating leaf powder at 5 , 10 and $15 \%$ levels. The results of the study revealed that products incorporated with 5\% of dried leaves were found most acceptable. It can be concluded from the study that the development and use of iron-rich value-added products from unconventional leaves can serve as a dietary approach to combat iron deficiency anemia. Tripathi et al., (2017) fortified mathri with malted Nutri flour and leaf powder mix. Malted Nutri flour contained $40 \mathrm{~g}$ malted wheat flour, $30 \mathrm{~g}$ malted pearl millet flour, and 30g malted barnyard millet flour. Leaf powder mix contained $50 \mathrm{~g}$ cauliflower leaves and $50 \mathrm{~g}$ turnip leaves. The Nutri flour and leaf powder mix were incorporated in the mathriat $100,95,90,85$, $80 \%$ and $0,5,10,15,20 \%$, respectively. The results of the study showed that mathri with the levels of Nutri flour at $95 \%$ and leaf powder mix at 5\% had the highest overall acceptability. The nutritional analysis showed that iron and protein content of fortified mathri were $14.59 \mathrm{mg} / 100 \mathrm{~g}$ and $16.71 \mathrm{~g} / 100 \mathrm{~g}$, respectively. Thus, it can be concluded that the Nutri flour and leaf powder mix isa good source of protein and iron may be incorporated in the daily diets of vulnerable sections of the population. Abdul Raheem et al., (2017) developed biscuits incorporated with dried cauliflower leaves. The results of the nutrient analysis showed that cauliflower leaves were rich in iron $(66.78 \mathrm{mg} / 100 \mathrm{~g})$ and beta carotene $(45.58 \mathrm{~g} / 100 \mathrm{~g})$. The leaf powder was incorporated at 5, 10 and $15 \%$ level in biscuits. Biscuits incorporated with $5 \%$ of leaf powder were found to be highly acceptable. It can be concluded from the study that biscuits developed from dried cauliflower leaf powder contained an appreciable amount of iron and $\beta$-carotene and can be useful in combating iron and vitamin A deficiency.

Joshi and Mathur (2010) developed valueadded products by incorporating dehydrated underutilized green leafy vegetables. $100 \mathrm{~g}$ of leaf powder mix contains $20 \mathrm{~g}$ beet greens, 40 g carrot greens, $20 \mathrm{~g}$ cauliflower greens, and $20 \mathrm{~g}$ turnip greens. The leaf powder mixture was incorporated at $0,5,10,15$ and $20 \%$ level in twenty different recipes. The results of the nutritional analysis showed that energy, protein, calcium, iron, zinc and polyphenol content of leaf powder mixture was 319.23 $\mathrm{Kcal} / 100$ g, $25.77 \%, 3.77 \%, 77.10 \mathrm{mg} \%, 2.52$ $\mathrm{mg} \%$, and $0.66 \%$, respectively. The incorporation of leaf powder mixture at a $10 \%$ level was found to be highly acceptable. Protein, iron, and calcium content were significantly higher in the leaf powder mixture incorporated recipes and the increase was directly proportional to the level of leaf mixture incorporated. Luthra and Sadana (1995) evaluated the supplementary effect of saagprepared from spinach, bathua, carrot and radish leaves on the protein quality of wheat chapati. Protein quality was evaluated by protein efficiency ratio and chemical score method.

The results of the study revealed that saags supplemented with wheat chapati in the ratio of 1:4 improved the protein efficiency ratio of wheat chapati. The chemical scores of lysine and tryptophan in the case of wheat chapati improved from 37 to 57 and 81 to 87, respectively, when supplemented with these saags.

Wani et al., (2013) studied the effect of incorporation of cauliflower leaf powder on quality attributes of malted wheat noodles. The wheat flour in noodle formulation was 
replaced by 10,15 and $20 \%$ of cauliflower leaf powder. The results of the study revealed that the rehydration ratio, reducing sugars and total sugars increased with increase in cauliflower leaf powder concentration, whereas water activity decreased. Among the various combinations, $90 \%$ malted wheat flour with $10 \%$ cauliflower leaf powder was found to be most acceptable. The results showed that cauliflower leaf powder can be incorporated up to $10 \%$ to increase nutrient value without affecting the sensory properties. Joshi and Mathur (2015) investigated the efficacy of leaf mixture on the hemoglobin level of anemic adolescent girls for a period of four months living in urban slums of Jaipur city. The leaf mixture was prepared by the combination of the leaf powders of four underutilized leaves of beet, carrot, turnip and cauliflower greens in the ratio of 1:2:1:1, respectively. The leaf mixture was incorporated in the chapati. The results of nutritional analysis showed that energy, protein, fat, carbohydrate, calcium, phosphorus, magnesium, iron, zinc content of leaf powder mixture was $319.23 \mathrm{Kcal}, 25.77$ g, $4.38 \mathrm{~g}, 44.16 \mathrm{~g}, 3.77 \mathrm{~g}, 0.50 \mathrm{~g}, 0.49 \mathrm{~g}, 77.10$ $\mathrm{mg}$ and $2.52 \mathrm{mg}$ per $100 \mathrm{~g}$, respectively. The results of the study revealed that fortification of food products with leaf mixture improved the hemoglobin level of anemic adolescent girls. Buvaneswari and Ramya (2014) studied the overall acceptability of food products incorporated with cauliflower leaves and its impact on treating anemic college going girls. The results of the nutrient analysis revealed that cauliflower leaves were rich in vitamin $\mathrm{C}$ $(54.27 \mathrm{mg} / 100 \mathrm{~g}), \beta$-carotene $(42.58 \mathrm{mg} / 100$ $\mathrm{g})$, protein $(28.98 \mathrm{gm} / 100 \mathrm{~g})$ and iron $(60.78$ $\mathrm{mg} / 100 \mathrm{~g}$ ). The leaf powder incorporated at a $5 \%$ level was highly acceptable in chocolate, cookies and green gram balls. Supplementation of food products fortified with cauliflower leaves increased the hemoglobin level of anemic girls. The study concluded that the supplementation of cauliflower leaves can be helpful in treating anemic adolescent college girls.

Wani and Sood (2014) studied the effect of incorporation of cauliflower leaf powder on the sensory and nutritional composition of malted wheat biscuits. The malted wheat flour was blended with cauliflower leaf powder at the levels of 10,20 and $30 \%$ for the development of biscuits. The results of the study revealed that moisture, crude protein, crude fiber, and ash content was found to be highest i.e., 1.68, 9.49, 13.32 and $1.49 \%$ in biscuits incorporated with $30 \%$ cauliflower leaf powder. Biscuits incorporated with $10 \%$ of cauliflower leaf powder were found to be most acceptable. Gupta et al., (2016) studied in vitro bioavailability of calcium in products incorporated with cauliflower leaves. The findings of the study revealed that paneer parantha incorporated with cauliflower leaves had $12.65 \mathrm{~g} / 100 \mathrm{~g}$ protein, $305.66 \mathrm{mg} / 100 \mathrm{~g}$ calcium, $10.92 \mathrm{mg} / 100 \mathrm{~g}$ iron and $39.2 \mu \mathrm{g} / 100$ $\mathrm{g}$ total carotene. The organoleptic characteristics and retention of ascorbic acid in commonly consumed food preparations using unconventional greens were studied by Kaur and Kochhar (2005). The results of the nutrient analysis showed that vitamin $\mathrm{C}$ content in cauliflower leaves, radish greens, turnip greens, and carrot greens were 96.87 $\mathrm{mg} / 100 \mathrm{~g}, 83.75 \mathrm{mg} / 100 \mathrm{~g}, 143.41 \mathrm{mg} / 100 \mathrm{~g}$ and $67.33 \mathrm{mg} / 100 \mathrm{~g}$, respectively. The food products developed by incorporation of unconventional greens of cauliflower, carrot, turnip, and radish were found to be organoleptically acceptable. Parantha was the only food preparation that was acceptable with the incorporation of all four underutilized greens. The level of incorporation for radish and turnip greens in parantha was 30 and 50\%, respectively. Singh et al., (2005) studied the nutritional composition of products prepared from cauliflower leaf powder. The study showed that the total iron content was maximum in the cake $(9.9 \mathrm{mg})$ whereas, ionizable iron was highest in biscuits (2.63 
mg). Protein content was maximum in kurmura (12.25\%) and minimum in biscuits $(7.42 \%)$. Ascorbic acid and beta carotene of biscuits, cake, namakpara, kurmura ranged from 2.21 to $4.29 \mathrm{mg}$ and 2.04 to $4.98 \mathrm{mg}$, respectively. Reema et al., (2004) incorporated $5 \%$ dried carrot greens in burfi and $5 \%$ colocasia greens in sevian. Sevian was found to be nutritionally superior due to higher ascorbic acid, beta carotene, protein, iron, calcium, and zinc content compared to burfi. Kaur and Kochhar (2009) incorporated fresh and dehydrated carrot greens in commonly consumed food preparations. The level of incorporation of fresh and dried carrot greens ranged between 40 to $80 \%$ and 7 to $9 \%$, respectively. In fresh carrot greens incorporated food preparations, the maximum and most acceptable level was $80 \%$ in saags and minimum (40\%) in puri and kadhi. In dry carrot greens incorporated food preparations, the most acceptable level was $9 \%$ in mathri.

Verma and Jain (2012) studied the nutritional composition of mathri supplemented with fresh and dried leaves of spinach, mint, and carrot. The nutritional evaluation showed that protein $(7.44 \mathrm{~g})$ and iron $(5.37 \mathrm{mg})$ in dried vegetable mathriwas higher as compared to fresh vegetables mathri. Kowsalya and Mohandas (1999) also studied the acceptability and nutrient profile of cauliflower leaves. Cauliflower leaves were incorporated into South Indian preparations such as porialand kotu. The leaves were also incorporated into common preparations like adai, vada and chapati at 10 and $20 \%$ levels. The results of the study revealed that cauliflower leaves are accepted well in its meal form as well as in the incorporated recipes (10 and 20\%). The nutrient profile of cauliflower leaves showed the presence of 32 $\mathrm{mg} / 100 \mathrm{~g}$ vitamin C, $21861 \mathrm{mg} / 100 \mathrm{~g}$ total carotene, $14731 \mathrm{mg} / 100 \mathrm{~g}$ beta carotene, 490 $\mathrm{mg} / 100 \mathrm{~g}$ calcium, $40 \mathrm{mg} / 100 \mathrm{~g}$ phosphorus and $1310 \mathrm{mg} / 100 \mathrm{~g}$ potassium. The leaves were excellent sources of antioxidants like $\beta$ carotene, vitamin $\mathrm{C}$ and minerals like selenium, copper, zinc, and iron. It was concluded that the development of products based on these vegetables may increase the nutritional value of regular Indian diets.

The unconventional greens are the powerhouse of essential nutrients and phytochemicals and had tremendous potential to help people overcome the deadly diseases owing to their significant antioxidant potential. The appropriate use of unconventional vegetable leaves can be an effective effort towards achieving the nutritional security of masses at low cost. Thus, it is recommended that the various value-added products from unconventional greens if incorporated in regular dietary patterns can be a healthy option for the general masses.

\section{References}

Abdel-Fattah S A. 2014. Biochemical and nutritional impact of celery and turnip leaves on induced obese by high fat diet (HFD). Journal of Food and Nutrition Sciences 2(6):285-302.

Abdul Raheem M I, Saboor S, Patil P S, Katke S D and Khan F D. 2017. Development and nutritional evaluation of biscuits prepared by using dried cauliflower (Brassica oleracea) leaves powder. Green Farming 8(2): 502-05.

Agarwal K and Varma R. 2014. Radical scavenging ability and biochemical screening of common asian vegetable RaphanssativsL. International Journal of Pharmaceutical Sciences Review and Research 27(1):127-134.

Ankita and Prasad K (2015) Characterization of dehydrated functional fractional radish leaf powder. Scholars Res Lib 7: 269-79.

Banka R, Sharma B, Sharma S and Goyal A. 2017. Development of iron rich value added products from underutilized 
leaves: a dietary approach to prevention deficiency anemia. International Journal of Pure \& Applied Bioscience 5(3): 415420.

Beevi S S, Narasu M L and Gowda B B. 2010. Polyphenolic profile, antioxidant and radical scavenging activity of leaves and stem of Rapahnus sativus L. Plant Foods for Human Nutrition 65(1):8-17.

Beltagy A M. 2014. Investigation of new antimicrobial and antioxidant activities of Brassica rapa L. International Journal of Pharmacy and Pharmaceutical Sciences 6(6):84-88.

Buvaneswari K M and Ramya G. 2014. A study on over all acceptability of Brassica oleracea leaves (cauliflower leaves) incorporated food products and its impact on treating anemic college going girls. International Journal of Current Research and Development 2(1):38-47.

Chakraborty S and Datta S. 2016. Estimation of macro-nutrients in domestically processed cauliflower leaf powder. International Journal of Science and Research 5(2):2094-2096.

Chauhan A and Inteli. 2015. Product development and sensory evaluation of value added food products made by incorporating dried cauliflower green leaves. Journal of Nutrition and Food Sciences 5(1):1-4.

De Almeida-Muradian L B, Rios M D and Sasaki R. 1998. Determination of provitamin A of green leafy vegetables by high performance liquid chromatography and open column chromatography. Boll ChimFarm 137(72): 290-94.

Devaraj V C, Krishna B G, Viswanatha G L, Prasad V S and Babu S N. 2011. Protective effect of leaves of Raphanus sativus L. on experimentally induced gastric ulcers in rats. Saudi Pharmaceutical Journal19(3): 171-176.

Eugenio M H A, Pereira R G F A, Abreu W C D and Pereira M C D A. 2017. Phenolic compounds and antioxidant activity of tuberous root leaves. International
Journal of Food Properties 20(12): 2966-2973.

Fernandes F, Sousa C, Pereira J A, Seabra R M, Andrade P B and Valentão P. 2007. Chemical and antioxidant assessment of dietary turnip (Brassica rapa). Food Chemistry 105:1003-1010.

Gopalan C, Ramasastri B V and Balasubramaniam S C (2009) Nutritive Value of Indian Foods. National Institute of Nutrition, Indian Council of Medical Research, Hyderabad.

Gupta S, Lakshmi J A, Manjunath M N and Prakash J. 2005. Analysis of nutrient and antinutrient content of underutilized green leafy vegetables. LWT Food Science and Technology38:339-45.

Gupta A, Gangwar K and Parihar R. 2016.In vitro bioavailability of calcium in products incorporated with green leafy vegetables. International Journal of Home Science 2(1):5-8.

Joshi P and Mathur B. 2010. Preparation of value added products from the leaf powders of dehydrated less utilized green leafy vegetables. Journal of Horticulture and Forestry 2(9): 223-228.

Joshi P and Mathur B. 2015. Effect of consumption of dehydrated green leaf mixture on the hemoglobin levels of the anemic adolescent girls. International Journal of Medical Science8(1\&2):1019.

Kaur T J and Kochar G K. 2005. Organoleptic evaluation and retention of vitamin $\mathrm{C}$ in commonly consumed food preparations using underexploited greens. The Indian Journal of Nutrition and Dietetics 42(9):425-31.

Kaur T J and Kochar G K (2009) Development and sensory evaluation of beta carotene rich food preparations using underexploited carrot greens. Journal of Human Ecology28(3):207-12.

Kowsalya S and Mohandas S. 1999. Acceptability and nutrient profile of cauliflower leaves (Brassica oleracea, var. botrytis).The Indian Journal of Nutrition \& Dietetics 36:332-38. 
Kulkarni L R (2003) Documentation, valuearization and promotion of underutilized foods for nutrition security of school children. Ph.D. Thesis. University of Agricultural Sciences, Dharwad, Karnataka, India.

Lakshminarayana R, Raju M, Krishnakantha T P and Baskaran V. 2005. Determination of major carotenoids in a few Indian leafy vegetables by high-performance liquid chromatography. Journal of Agriculture and Food Chemistry53(8):2838:2842.

Leite C W, Boroski M, Boeing J S, Aguiar A C, Franca P B, Souza N E D and Visentainer J V. 2011. Chemical characterization of leaves of organically grown carrot (Dacus carota L.) in various stages of development for use as food. CiêncTecnol Aliment Campinas 31(3):735-738.

Longvah T, Ananthan R, Bhaskarchary K and Venkaiah (2017) Indian Food Composition Tables. National Institute of Nutrition, Indian Council of Medical Research, Hyderabad.

Luthra G and Sadana B. 1995. Potential of improving protein quality of wheat chapatti by addition of bathu (Chenopodiu album), carrot (Daucus carota) and radish (Raphanus sativus) leaves.Journal of Food Science \& Technology32(6):507-509.

Martin J G P, Porto E, Corrêa C B, Alencar S M, Gloria E M, Cabral I S R and Aquino L M. 2012. Antimicrobial potential and chemical composition of agro-industrial wastes. Journal of Natural Products5: 27-36.

Meena S, Agarwal M and Agarwal K. 2015. Effect of blanching and drying on antioxidants and antioxidant activity of selected green leafy vegetables. International Journal of Science and Research 5(10):1811-14.

Mohankumar J B and Bhavani K. 2004. The efficacy of cauliflower greens (Brassica olerceal var botrytis) preparation in improving blood hemoglobin in selected adolescent girls. The Indian Journal of
Nutrition and Dietetics 41(2): 63-66.

Moyo M, Amoo S O, Ncube B, Ndhlala A R, Finnie J F and Van Staden J. 2013. Phytochemical and antioxidant properties of unconventional leafy vegetables consumed in southern Africa. South African Journal of Botany84:6571.

Nnamani C V, Oselebe H O and Agbatutu A. 2009. Assessment of nutritional values of three underutilized indigenous leafy vegetables of Ebonyi State, Nigeria. African Journal of Biotechnology8 (9): 2321-24.

Pandey A K, Dubey R K, Singh V and Vida E. 2014. Addressing the problem of micronutrient malnutrition in Neh region-underutilized vegetables as a source of food. International Journal of Food and Nutritional Science 3 (3): 77 83.

Pattan and Devi C U. 2014. Micronutrient and anti nutrient components of selected unconventional leafy vegetables in Bangalore city, India. Research Journal of Recent Science 3:393-95.

Reddy P V, Desai S, Ahmed F and Urooj A. 2010. Antioxidant properties and stability of Raphanus sativus extracts. Journal of Pharmacy Research3:658661.

Reema, Hira C K and Sadana B. 2004. Nutritional evaluation of supplementary foods prepared from germinated cereal and legumes. Journal of Food Science \& Technology41:627-29.

Romani A, Vignolini $\mathrm{P}$, Isolani L, Ieri $\mathrm{F}$ and Heimler D. 2006. HPLC-DAD/MS characterization of flavonoids and hydroxycinnamic derivatives in turnip tops (Brassica rapa L. Subsp. Sylvestris L.). Journal of Agricultural and Food Chemistry54(4):1342-1346.

Sadana B and Hira. 2004. Nutritional evaluation of saags prepared from unconventional leaves. Indian Journal of Ecology31:167-69.

Saeed M K, Anjum S, Ahmad I, Alim-un-Nisa, Ali S, Zia A and Ali S. 2012. Nutritional 
facts and free radical scavenging activity of turnip (Brassica rapa) from Pakistan. World Applied Sciences Journal 19(3): 370-375.

Shah B A (2005) Value addition of traditional diets for iron with Bengal gram leaves. M.Sc. Thesis. Marathwada Agricultural University, Parbhani, Maharashtra, India.

Sheela K, Nath K G, Vijayalakshmi D, Yankanchi G M and Patil R B. 2004. Proximate composition of underutilized green leafy vegetables in southern Karnataka. Journal of Human Ecology 15(3): 227-29.

Shehata A N, Mahmoud A E and Abdou H M. 2014. Quantification of total phenolic and total flavonoids contents in extracts of some Egyptian green leaves and estimation of antioxidant activity. Research Journal of Pharmaceutical, Biological and Chemical Sciences 5(6):266-273.

Siddiqui M H, Khan M M A, Khan M N, Mohammad F and Naeem M. 2006. Hill reaction, photosynthesis and chlorophyll content in non-sugar-producing (turnip, Brassica rapa L.) and sugar-producing (sugar beet, Beta vulgaris L). Turkish Journal of Biology 30:153-155.

Singh G, Kawatra A and Sehgal S. 2001. Nutritional composition of selected green leafy vegetables, herbs and carrots. Plant Foods for Human Nutrition 56:359-64.

Singh P and Awasthi P (2003) Sensory and nutritional quality evaluation of green leafy vegetable powder incorporated food products. Proceedings of
International Food Conference 5507:77.

Singh G, Kawatra A and Sehgal S. 2005. Development and nutritional evaluation of products prepared from dried powder of cauliflower leaves. Journal of Food Science \& Technology 42(2):137-39.

Tripathi J, Prasad R, Verma A and Gupta A. 2017. Fortification of mathri with malted nutri flour and leaf powder mix and assessment of organoleptic and nutritional attributes. World Journal of a Pharmacy and Pharmaceutical Sciences6(8):2141-49.

Uusiku N P, Oelofse A, Duodu K G, Bester M J and Faber M. 2010. Nutritional value of leafy vegetables of sub-Saharan Africa and their potential contribution to human health: a review. Journal of Food Composition and Analysis 23(6):499509.

Verma S and Jain S (2012) Fortification of mathri with fresh and dehydrated vegetables and assessment of nutritional quality. Rajasthan Journal of Extension Education20:155-158.

Wani T A, Sood M and Kaul R K and Gupta M. 2013. Effect of incorporation of cauliflower leaf powder on quality attributes of malted wheat noodles. African Journal of Biotechnology 13(9):1019-1026.

Wani T A and Sood M. 2014. Effect of incorporation of cauliflower leaf powder on sensory and nutritional composition of malted wheat biscuits. African Journal of Biotechnology13(9):10191026.

\section{How to cite this article:}

Nidhi Joshi and Kiran Bains. 2019. Bringing Unconventional Greens from Fodder to Fork: A Review. Int.J.Curr.Microbiol.App.Sci. 8(10): 2125-2136. doi: https://doi.org/10.20546/ijcmas.2019.810.247 